\title{
Antiviral activity of mycosynthesized silver nanoparticles against herpes simplex virus and human parainfluenza virus type 3
}

This article was published in the following Dove Press journal:

International Journal of Nanomedicine

5 November 2013

Number of times this article has been viewed

\author{
Swapnil Gaikwad' \\ Avinash Ingle \\ Aniket Gade' \\ Mahendra Rai' \\ Annarita Falanga ${ }^{3}$ \\ Novella Incoronato ${ }^{2}$ \\ Luigi Russo ${ }^{2}$ \\ Stefania Galdiero ${ }^{3}$ \\ Massimilano Galdiero ${ }^{2}$ \\ 'Department of Biotechnology, Sant \\ Gadge Baba Amravati University, \\ Amravati, Maharashtra, India; \\ ${ }^{2}$ Department of Experimental \\ Medicine, Division of Microbiology, \\ II University of Naples, ${ }^{3}$ Department \\ of Pharmacy, University of Naples \\ "Federico II", DFM and Institute of \\ Biostructures and Bioimages, \\ Naples, Italy
}

\begin{abstract}
The interaction between silver nanoparticles and viruses is attracting great interest due to the potential antiviral activity of these particles, and is the subject of much research effort in the treatment of infectious diseases. In this work, we demonstrate that silver nanoparticles undergo a size-dependent interaction with herpes simplex virus types 1 and 2 and with human parainfluenza virus type 3 . We show that production of silver nanoparticles from different fungi is feasible, and their antiviral activity is dependent on the production system used. Silver nanoparticles are capable of reducing viral infectivity, probably by blocking interaction of the virus with the cell, which might depend on the size and zeta potential of the silver nanoparticles. Smaller-sized nanoparticles were able to inhibit the infectivity of the viruses analyzed.
\end{abstract}

Keywords: silver nanoparticles, antiviral, herpes simplex virus, parainfluenza virus

\section{Introduction}

The world population faces the problem of viral infection and the various lifethreatening diseases caused by different viruses, such as the common cold, influenza, hepatitis, chickenpox, infectious mononucleosis, herpes keratitis, human immunodeficiency virus, and viral encephalitis. Much effort has been made to develop medicines and vaccines against a number of viruses. ${ }^{1,2}$ Although tremendous improvement has been made from time to time in the field of antiviral therapy, medicines are unable to completely prevent all viral disease. Hence, it is essential to develop antiviral agents which can act against a broad range of viruses. Herpes simplex virus types 1 and 2 (HSV-1 and HSV-2, respectively) and human parainfluenza virus type 3 (HPIV-3) are important viruses because they can cause serious infection in humans.

Despite the continued global epidemic of herpes simplex virus and extensive research, there have been few major breakthroughs in the treatment or prevention of this virus since the introduction of aciclovir in the 1980s. Resistance of herpes simplex virus to aciclovir has become an important clinical problem, especially in immunocompromised patients undergoing long-term therapy. Viral resistance to aciclovir usually arises from mutations in the viral thymidine kinase gene, although mutations in the viral DNA polymerase gene may also occur. Resistant isolates can cause severe, progressive, and debilitating mucosal disease and, rarely, visceral dissemination. ${ }^{3}$ Available reports suggest that infection caused by these viruses can be avoided to some extent by inhibiting their DNA replication. The phenolic compounds extracted from rosemary, a spice plant (Rosmarinus officinalis L), avoid HSV-1 infection in African green monkey kidney (Vero) cells, thereby inhibiting replication of viral DNA. ${ }^{4}$ Hashem et $\mathrm{al}^{5}$ investigated the potential
Correspondence: Stefania Galdiero Department of Pharmacy, University of Naples "Federico II", Via D. Montesano, 4980 I3I Naples, Italy

Tel $+3908 I 2534503$

Fax +3908 12534560

Email stefania.galdiero@unina.it 
of aurintricarboxylic acid, a potent inhibitor of nucleic acid-processing enzymes, to protect Madin-Darby canine kidney cells from influenza infection. Analysis carried out by neutral red assay, reverse transcriptase polymerase chain reaction, and enzyme-linked immunosorbent assay confirmed that aurintricarboxylic acid reduced viral replication to a considerable extent.

Modifications of existing antiviral compounds and development of novel antiviral agents is a prime area of research. Nanotechnology provides a golden platform to modify and develop the properties of pure metals by converting them into their nanoform (nanoparticles), which has applications in numerous fields like diagnostics, drug delivery, antimicrobial agents, and treatment of various other diseases. ${ }^{6}$ In particular, nanotechnology represents a novel challenge for the treatment of viral infection.

Metal nanoparticles can be synthesized by physical, chemical, and biological methods. The latter technique has demonstrated many advantages over physical and chemical methods. A number of biological agents including bacteria, ${ }^{7}$ actinomycetes, ${ }^{8}$ algae, ${ }^{9}$ plants,${ }^{10-12}$ and fungi ${ }^{13-21}$ have been used successfully for synthesis of metal nanoparticles, including silver nanoparticles (AgNPs).

In addition, the antimicrobial potential of metal nanoparticles synthesized using different methods has been evaluated against a wide range of bacteria, including multidrug-resistant organisms ${ }^{16}$ and fungal pathogens. ${ }^{15,22}$ These studies showed potential antibacterial activity against both Gram-negative and Gram-positive bacteria. ${ }^{14,19,23-25}$ Any metal nanoparticle could be evaluated for antiviral activity; however, little effort has already been devoted to the determination of nanoparticle's antiviral activity and their interactions with viruses.

Recent studies have shown that metal nanoparticles, particularly AgNPs, can be effective agents against a number of types of virus ${ }^{26}$ Rogers et $\mathrm{al}^{27}$ reported the antiviral activity of AgNPs (10-80 nm) with or without a polysaccharide coating against Monkeypox virus. Their results demonstrated that AgNPs approximately $10 \mathrm{~nm}$ in size significantly inhibit Monkeypox virus infection in vitro, supporting their potential use as a therapeutic antiviral agent. Speshock et $\mathrm{al}^{28}$ demonstrated the interaction of AgNPs with Tacaribe virus and their effect on viral replication. In particular, virus treated with AgNPs showed significant reduction in viral RNA production and release of progeny virus, which supports the view that AgNPs are capable of inhibiting Tacaribe virus infection in vitro. There are other studies on the activity of AgNPs against human immunodeficiency virus $1,{ }^{29}$ hepatitis B virus,${ }^{30}$ respiratory syncytial virus,${ }^{31}$ herpes simplex virus type $1,{ }^{32}$ and influenza viruses. ${ }^{33}$ The present study evaluated the antiviral activity of AgNPs produced by fungi against HSV-1, HSV-2, and HPIV-3.

\section{Materials and methods Isolation of fungi from plants}

Infected leaves of Dryopteris (fern) species, Musa paradisiaca, Catharanthus roseus, Selaginella bryopteris, and Syzygium cumini were collected and the associated fungi were isolated on potato dextrose agar. The fungi were identified on the basis of morphological and cultural characteristics. Identification confirmed the association of five different fungi, which were used for further study.

\section{Synthesis of AgNPs}

The selected fungi were grown in $250 \mathrm{~mL}$ flasks containing $100 \mathrm{~mL}$ of potato dextrose broth at $28^{\circ} \mathrm{C}$ for 72 hours. The biomass was then harvested and filtered through Whatman filter paper No 1 . The fungal mats were then washed with distilled water to remove the medium components and suspended in $100 \mathrm{~mL}$ of distilled water for 48 hours. Next, the cell filtrate was separated by filtration. The cell filtrate for each fungus was collected and challenged with $\mathrm{AgNO}_{3}$ salt (final concentration $1 \mathrm{mM}$ ).

\section{Characterization of AgNPs \\ Ultraviolet-visible spectrophotometry}

After complete reduction of the silver ions, the reaction mixture was subjected to ultraviolet-visible analysis using a UV-1700 spectrophotometer (Shimadzu, Tokyo, Japan). The spectrum was scanned at a resolution of $1 \mathrm{~nm}$ from $200 \mathrm{~nm}$ to $800 \mathrm{~nm}$ for each sample.

\section{Nanoparticle tracking and analysis}

The samples were diluted with nuclease-free water, and $0.5 \mathrm{~mL}$ of each diluted sample was injected into the sample chamber and observed using a Nanosight LM 20 device (NanoSight Ltd., Amesbury, UK) to measure the size of the nanoparticles.

\section{Transmission electron microscopy}

The AgNPs were also characterized by transmission electron microscopy (CM 12; Philips, Eindhoven, the Netherlands) on conventional carbon-coated copper grids (400 mesh; Plano GmbH, Wetzlar, Germany). A $5 \mu \mathrm{L}$ sample was used for characterization and three images of each sample were taken to clarify the composition. 


\section{Zeta potential measurement}

The zeta potential was measured using a Zetasizer (3000 HS; Malvern Instruments, Malvern, UK) with a zeta dip cell. Sample preparation for zeta analysis involved 1:10 dilution of the biosynthesized AgNPs in $1 \mathrm{mM} \mathrm{KCL}$; the total volume of the sample $(1 \mathrm{~mL})$ was put into a clear disposable zeta cell for measurement of zeta potential.

\section{Cells and viruses}

Vero cells (CCL-81; American Type Culture Collection, Manassas, VA, USA) were grown in Dulbecco's Modified Eagle's Medium supplemented with $10 \%$ fetal calf serum. HSV-1 (strain SC16) and HSV-2 (strain 333), both carrying a $L a c Z$ gene driven by the cytomegalovirus IE-1 promoter to express $\beta$-galactosidase, were propagated on Vero cell monolayers. HPIV-3 (strain C-243) was also propagated on Vero cell monolayers.

\section{Cytotoxicity studies}

To confirm that the AgNPs did not exert toxic effects on cells, the Vero cell monolayers were exposed to increasing concentrations of each compound, and the number of viable cells was determined using the 3-(4,5-dimethylthiazol-2-yl)-2,5diphenyltetrazolium bromide (MTT) assay, which is based on reduction of yellowish MTT to insoluble and dark blue formazan by viable and metabolically active cells. The Vero cells were subcultured in 96-well plates at a seeding density of $2 \times 10^{4}$ cells/well and treated with AgNPs produced in Alternaria species, Fusarium oxysporum, Curvularia species, Chaetomium indicum, and Phoma species at concentrations of $1,5,10,50$, and $100 \mu \mathrm{g} / \mathrm{mL}$ for $1,3,10,24$, and 36 hours. The medium was gently aspirated, MTT solution $(5 \mathrm{mg} / \mathrm{mL})$ was added to each well, and the cells were incubated for a further 3 hours at $37^{\circ} \mathrm{C}$. The medium with MTT solution was removed, and the formazan crystals were dissolved with dimethylsulfoxide. The absorption values were measured at $570 \mathrm{~nm}$ using a microplate reader (Bio-Rad Laboratories Inc., Hercules, CA, USA). Vero cell viability in each well is presented as a percentage of control cells.

\section{Assessment of antiviral activity}

For all the experiments below, AgNPs were dissolved in Dulbecco's Modified Eagle's Medium without serum and used at concentrations of $0.1,0.5,1,5$, and $10 \mu \mathrm{g} / \mathrm{mL}$. Percent inhibition of infectivity was calculated by setting the number of plaques obtained in positive controls, where no antiviral compounds were added to the cell monolayers, to $0 \%$ inhibition. Different methods were used to treat the cell monolayers to assess the effect of AgNPs on inhibition of HSV-1, HSV-2, and HPIV-3 infectivity. ${ }^{34}$

\section{Cotreatment assay}

Confluent Vero cell monolayers (12-well plates) were washed with phosphate-buffered saline and infected with either HSV-1, HSV-2, or HPIV-3 at a multiplicity of infection of 0.02 plaque-forming units per cell for 1 hour at $37^{\circ} \mathrm{C}$. The virus inocula were mixed with the AgNPs to be tested in each experiment as stated above. Nonpenetrated viruses were inactivated by citrate buffer at $\mathrm{pH}$ 3.0. The infected cells were washed with phosphate-buffered saline, overlaid with fresh culture medium supplemented with carboxymethyl cellulose, and incubated for 48 hours (for the two HSV serotypes) or 72 hours (for HPIV-3). Monolayers infected with HSV-1 and HSV-2 were fixed and stained with X-gal (5-bromo4-chloro-3-indolyl- $\beta$-D-galactopyranoside). After fixing, the plates infected with HPIV-3 were stained with crystal violet. In both cases, plaques were counted microscopically. The mean plaque counts for each drug concentration were expressed as a percentage of the mean plaque count for the control virus. The number of plaques was plotted as a function of drug concentration.

\section{Cell pretreatment assay}

Confluent Vero cell monolayers (12 well-plates) were treated as above with AgNPs for 1 hour at $37^{\circ} \mathrm{C}$ and then infected with HSV-1, HSV-2, or HPIV-3 at a multiplicity of infection of 0.02 plaque-forming units per cell for 45 minutes at $37^{\circ} \mathrm{C}$. The cells were then washed three times with Dulbecco's Modified Eagle's Medium to remove unattached virus and nanoparticles, overlaid with carboxymethyl cellulose, and incubated for 2 days (HSV-1 and HSV-2) or 3 days (HPIV3) at $37^{\circ} \mathrm{C}$. After fixing, plates infected with HPIV-3 were stained with crystal violet, whereas plates infected with the HSV serotypes were fixed and stained with X-gal. In both cases, the number of plaques was scored.

\section{Cell post-treatment assay}

Vero cell monolayers (12-well plates) were incubated with HSV-1, HSV-2, or HPIV-3 for 45 minutes at $37^{\circ} \mathrm{C}$. The AgNPs were then added to the inoculum followed by further incubation for 1 hour at $37^{\circ} \mathrm{C}$. For all treatments, nonpenetrated viruses were inactivated by citrate buffer at $\mathrm{pH} 3.0$ after the 45-minute incubation with cells at $37^{\circ} \mathrm{C}$. Cells infected with the HSV serotypes were then incubated for 48 hours, or 72 hours at $37^{\circ} \mathrm{C}$ for the Vero monolayers infected with HPIV-3, in Minimum Essential Dulbecco's Modified Eagle's Medium 
supplemented with carboxymethyl cellulose. The monolayers were fixed, stained with X-gal (HSV-1 and HSV-2) or crystal violet (HPIV-3), and plaque numbers were scored.

\section{Virus pretreatment assay}

First, $2 \times 10^{4}$ plaque-forming units of virus were incubated in the presence of different concentrations of AgNPs for 2 hours at $37^{\circ} \mathrm{C}$, then titrated on the cell monolayers. After incubation, the samples were diluted with medium to reduce the concentration of the antiviral compound to one that was not active in an antiviral assay. The multiplicity of infection of the viruses after dilution was 0.01 plaque-forming units per cell. The monolayers were fixed, stained with $\mathrm{X}$-gal (HSV-1 and HSV-2) or crystal violet (HPIV-3), and plaque numbers were scored.

\section{Results and discussion Isolation and identification of fungi from plants}

The types of fungi recovered from the infected leaves of host plants on potato dextrose agar were identified. Detailed morphological, cultural, and microscopic characters including growth rate of the colony, colony diameter, color of mycelium (dorsal and ventral), texture of colony, type of mycelium, presence or absence of conidia/spores, shape of conidia/ spores, and shape of conidia alone were recorded with the help of standard books and keys used for identification of fungi. ${ }^{34}$ These fungal species were confirmed as Alternaria species, F. oxysporum, Curvularia species, C. indicum, and Phoma species (Figure 1A) recovered from the leaves of Dryopteris species, M. paradisiaca, C. roseus, and $S$. bryopteris.

\section{Synthesis and characterization of AgNPs}

Biological synthesis of AgNPs using fungi was found to be a rapid method; in fact, a rapid change in color of the fungal cell filtrate was observed from yellowish or colorless to yellowish-brown when treated with aqueous $\mathrm{AgNO}_{3}$. The change in color was due to the reduction of silver ions $\left(\mathrm{Ag}^{+}\right)$to $\mathrm{AgNPs}\left(\mathrm{Ag}^{0}\right)$, indicating formation of $\mathrm{AgNPs}$ (Figure 1B inset). The intensity of color change increased with an increase in treatment duration. The five fungal cell filtrates, (ie, Alternaria species, F. oxysporum, Curvularia species, $C$. indicum, and Phoma species) enabled synthesis of AgNPs when treated with aqueous $\mathrm{AgNO}_{3}$. Our data support previous studies reporting the appearance of a yellowishbrown color after treatment of different fungi with $\mathrm{AgNO}_{3}$ solution..$^{20,21,24,35,36}$ Our findings also agree with previous studies carried out using different fungi as biological agents for the synthesis of AgNPs. ${ }^{13,15-17,19,25,37,38}$

Primary detection of the biosynthesized AgNPs using ultraviolet-visible spectrophotometry showed absorbance peaks in the range of $413-435 \mathrm{~nm}$, which is a typical range for AgNPs (413 nm for Alternaria species, $435 \mathrm{~nm}$ for F. oxysporum, $420 \mathrm{~nm}$ for Curvularia species, $423 \mathrm{~nm}$ for $C$. indicum, and $415 \mathrm{~nm}$ for Phoma species) $)^{16,22,39-41}$ (Figure 1B). The change in color of the fungal cell filtrate and absorption at around $420-450 \mathrm{~nm}$ is determined by the change in optical properties of the material during conversion from the bulk to the nanoform and is due to excitation of surface plasmon vibrations in the nanoparticles. ${ }^{41}$

Nanoparticle tracking analysis of AgNPs is based on tracking the Brownian motion of each particle and thus depends on the size of the nanoparticles. Nanoparticle tracking analysis revealed the average size of the nanoparticles to be $46 \mathrm{~nm}, 20 \mathrm{~nm}, 30 \mathrm{~nm}, 50 \mathrm{~nm}$, and $40 \mathrm{~nm}$ for Alternaria species, F. oxysporum, Curvularia species, C. indicum, and Phoma species, respectively. Figure 2 shows the particle size distribution histograms for the five samples. In addition, other details like mean, mode, standard deviation, and concentration of nanoparticles were determined and are reported in Table 1. Unlike classical light scattering techniques, nanoparticle tracking analysis allows measurement of nanoparticles in suspension on a particle-by-particle basis with real time visualization, sizing, and counting at higher resolution, so allows better understanding of aggregation than other methods, such as dynamic light scattering and differential centrifugation sedimentation. ${ }^{42,43}$

Transmission electron microscopy confirmed spherical and polydispersed AgNPs in the reaction mixture. The diameters of the nanoparticles were found to be in the size range of 7-20 nm for Alternaria species, 4-13 nm for F. oxysporum, 5-23 nm for Curvularia species, 10-31 nm for C. indicum, and 7-20 nm for Phoma species (Figure 3).

Finally, all the samples were characterized to determine their surface zeta potential, which gives an indication of the potential stability of a colloidal system. If all particles in a suspension have a large negative or positive zeta potential then they will tend to repel each other and there will be no tendency for the particles to come together. ${ }^{44}$ However, if the particles have low zeta potential values, there will be no force to prevent the particles coming together and forming aggregates of successively increasing size, which may settle out under the influence of gravity. Moreover, the noble properties exhibited by the nanoparticles are due to their nanosize; 

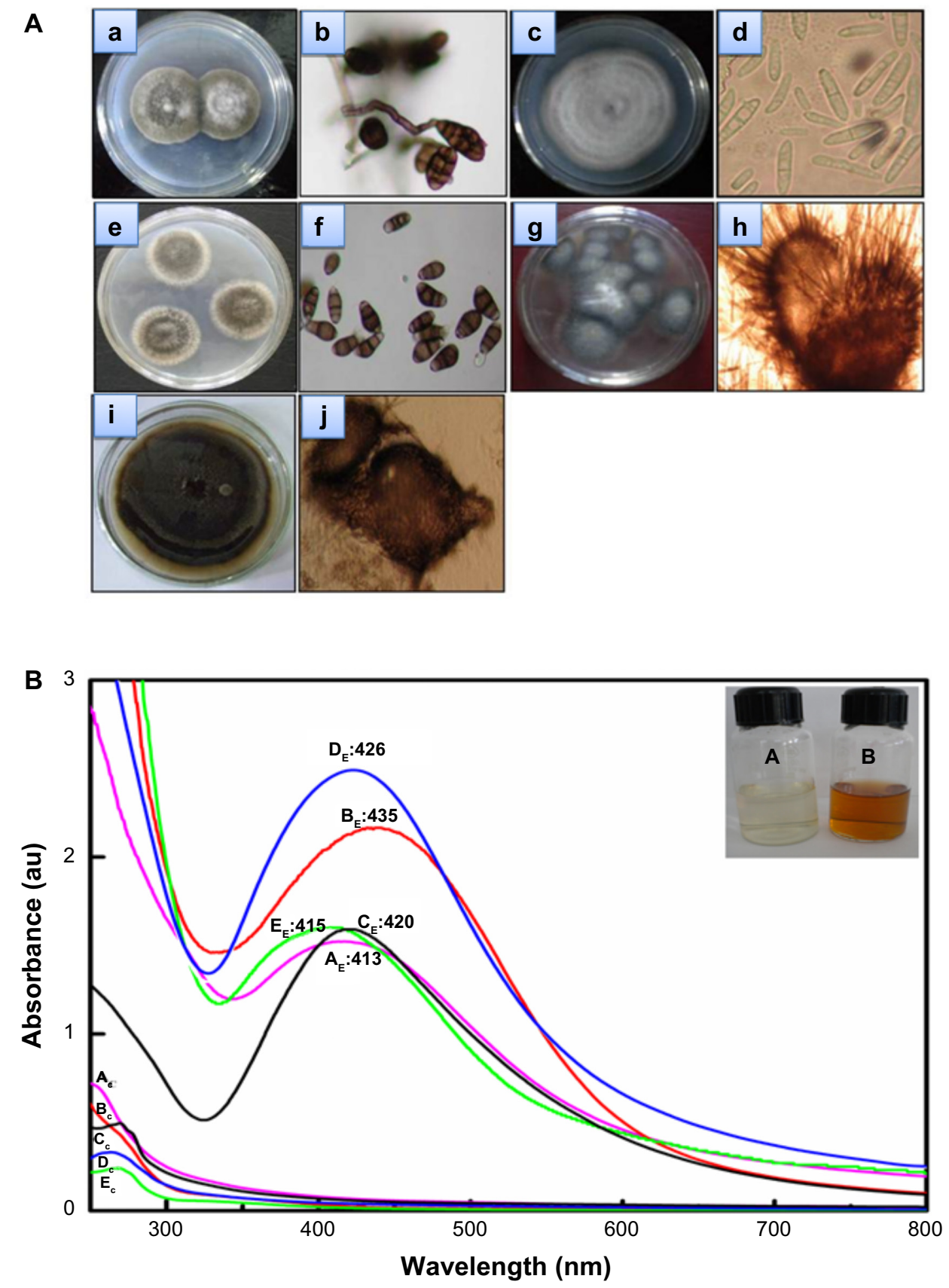

Figure I (A) Morphology of fungi observed by optical microscopy. Growth of Alternaria species (a) colony on potato dextrose agar, (b) conidia; Fusarium oxysporum, (c) colony on potato dextrose agar, (d) macroconidia; Curvularia species, (e) colony on potato dextrose agar, (f) conidia; Chaetomium indicum (g) colony on potato dextrose agar, (h) pycnidium and setae; Phoma species, (i) colony on potato dextrose agar, and (j) pycnidia of Phoma species. (B) Ultraviolet-visible spectra of five fungal cell filtrates (control, inset $\mathbf{A})$. ( $\left.\mathbf{A}_{\mathrm{C}}\right),\left(\mathbf{B}_{\mathrm{c}}\right),\left(\mathbf{C}_{\mathrm{C}}\right),\left(\mathbf{D}_{\mathrm{C}}\right),\left(\mathbf{E}_{\mathrm{c}}\right)$ and silver nanoparticles (experimental, inset $\left.\mathbf{B}\right)$. $\left(\mathbf{A}_{\mathrm{E}}\right),\left(\mathbf{B}_{\mathrm{E}}\right),\left(\mathbf{C}_{\mathrm{E}}\right),\left(\mathbf{D}_{\mathrm{E}}\right)$, and $\left(\mathbf{E}_{\mathrm{E}}\right)$ for Alternaria species, F. oxysporum, Curvularia species, $\mathbf{C}$. indicum and Phoma species, respectively.

by forming an aggregate, the size of the particle changes, thereby changing its properties. Zeta potential measurements for all samples synthesized from the five different fungi were recorded. These zeta potential values fall between -21.4 and $-37.0 \mathrm{mV}$ (-31.5 for Alternaria species, -32.9 for F. oxysporum, -22.1 for Curvularia species, -21.4 for C. indicum, and -37.0 for Phoma species, Table 2). These values confirm full stabilization of the nanoparticles and the fact that the chances of aggregation are very low because of their narrow size distribution.

\section{Cytotoxicity studies}

To rule out the possibility that the reduction of infectivity could be caused by cellular toxicity, monolayers of Vero cells were incubated with different concentrations $(1,5,10$, 50 , and $100 \mu \mathrm{g} / \mathrm{mL}$ ) of each different type of AgNPs for 


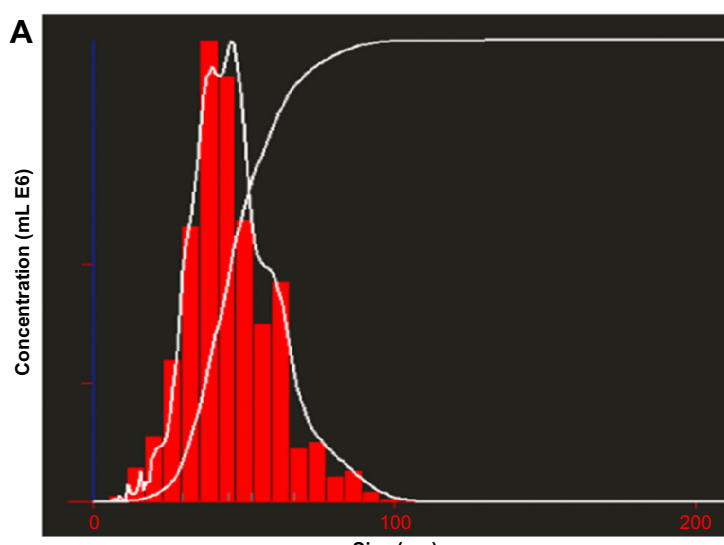

Size $(\mathrm{nm})$

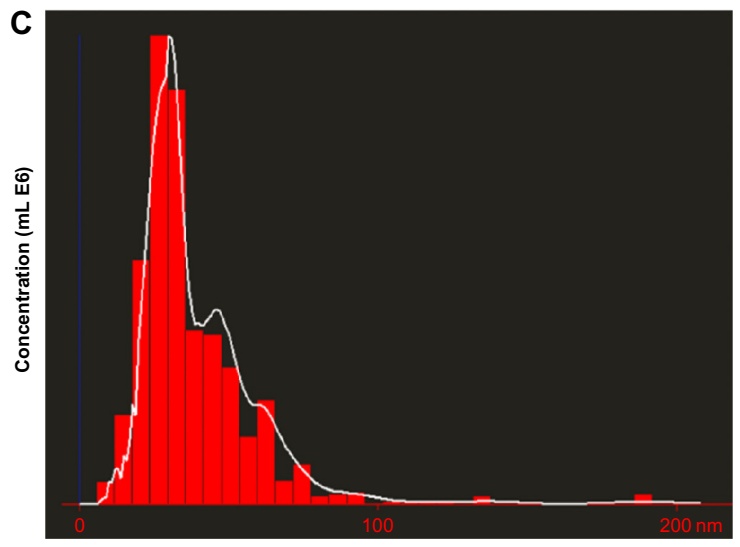

Size $(\mathrm{nm})$

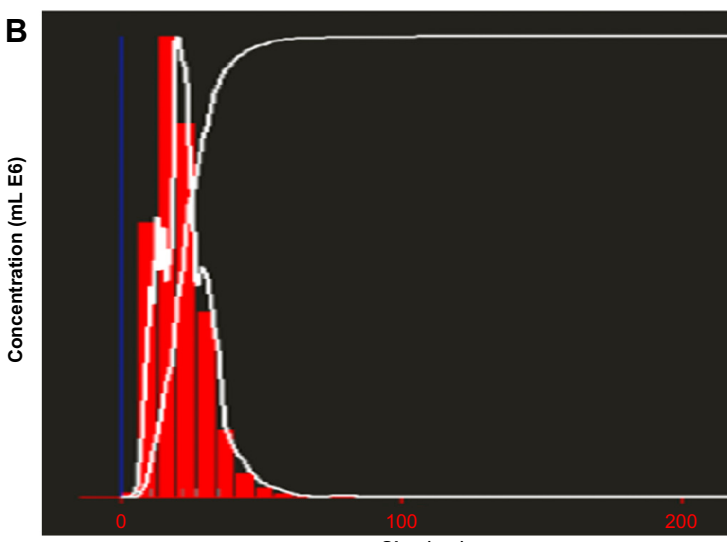

Size $(\mathrm{nm})$

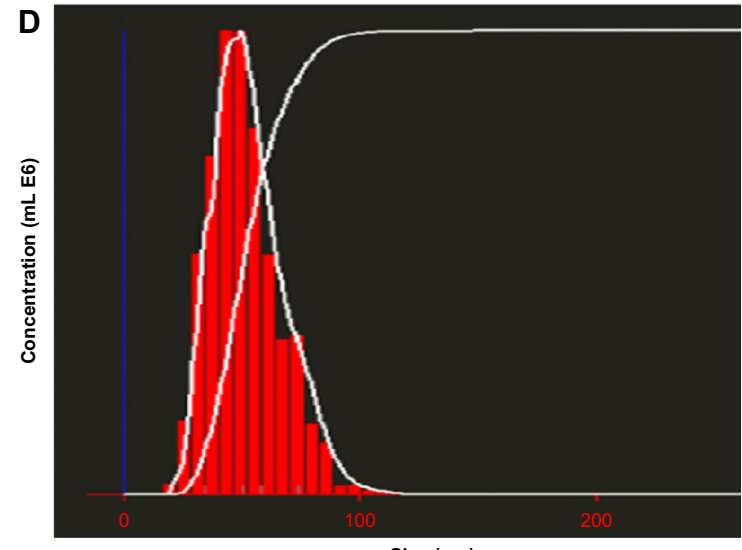

Size $(\mathrm{nm})$

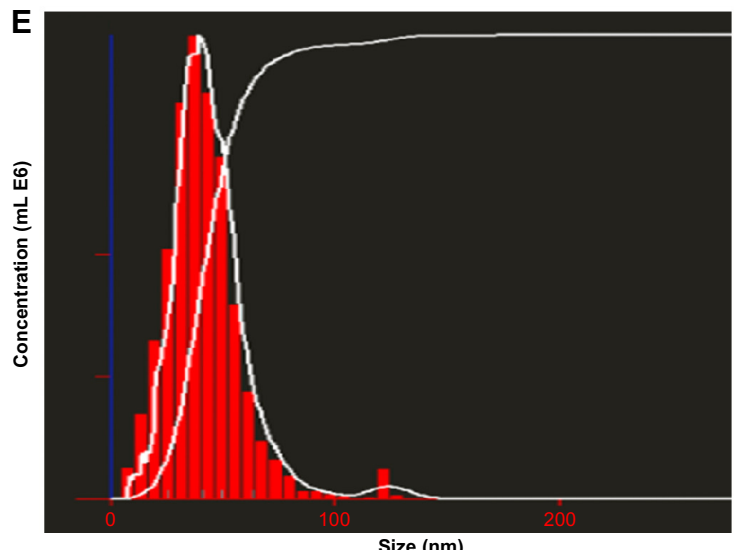

Size $(\mathrm{nm})$

Figure 2 Nanoparticle tracking analysis (Nanosight-LM 20; NanoSight Ltd., Amesbury, UK) to detect the number and size of the nanoparticles in real time. The histogram shows the nanoparticle size distribution (A) Alternaria species, $46 \mathrm{~nm}$, (B) Fusarium oxysporum, $20 \mathrm{~nm}$, (C) Curvularia species, $30 \mathrm{~nm}$, (D) Chaetomium indicum, $50 \mathrm{~nm}$, and (E) Phoma species, $40 \mathrm{~nm}$.

Abbreviation: Con $/ \mathrm{mL}$ E6, concentration $/ \mathrm{mL} \times 10^{6}$

Table I Particle size (mean, mode, and standard deviation) and concentration of silver nanoparticles determined by nanoparticle tracking analysis

\begin{tabular}{|c|c|c|c|c|c|}
\hline SN & $\begin{array}{l}\text { AgNPs synthesized } \\
\text { fungi }\end{array}$ & $\begin{array}{l}\text { Mean } \\
(\mathrm{nm})\end{array}$ & $\begin{array}{l}\text { Mode } \\
(\mathrm{nm})\end{array}$ & $\begin{array}{l}\text { SD } \\
(\mathrm{nm})\end{array}$ & $\begin{array}{l}\text { Concentration } \\
\text { (particles } / \mathrm{mL} \text { ) }\end{array}$ \\
\hline I & Alternaria species & 47 & 46 & 14 & $3.20 \times 10^{9}$ \\
\hline 2 & Fusarium oxysporum & 24 & 20 & 9 & $0.21 \times 10^{8}$ \\
\hline 3 & Curvularia species & 41 & 30 & 25 & $8.59 \times 10^{8}$ \\
\hline 4 & Chaetomium indicum & 53 & 50 & 15 & $4.25 \times 10^{8}$ \\
\hline 5 & Phoma species & 45 & 40 & 18 & $3.11 \times 10^{9}$ \\
\hline
\end{tabular}

Abbreviations: SD, standard deviation; SN, sample number; AgNPs, silver nanoparticles. different time points $(1,3,10,24$, and 36 hours) and cell viability was quantified by the MTT assay (data not shown). Nanoparticles produced by the Alternaria and Phoma species had toxic effects after 10 hours of incubation in the concentration range of $5-10 \mu \mathrm{g} / \mathrm{mL}$, while nanoparticles produced in F. oxysporum, Curvularia species, and C. indicum showed very minor cytotoxicity in Vero cells. We did not observe a decrease in cell viability up to $50 \mu \mathrm{g} / \mathrm{mL}$ for nanoparticles produced in F. oxysporum and C. indicum. These data were important for deciding on the concentrations to be tested in 

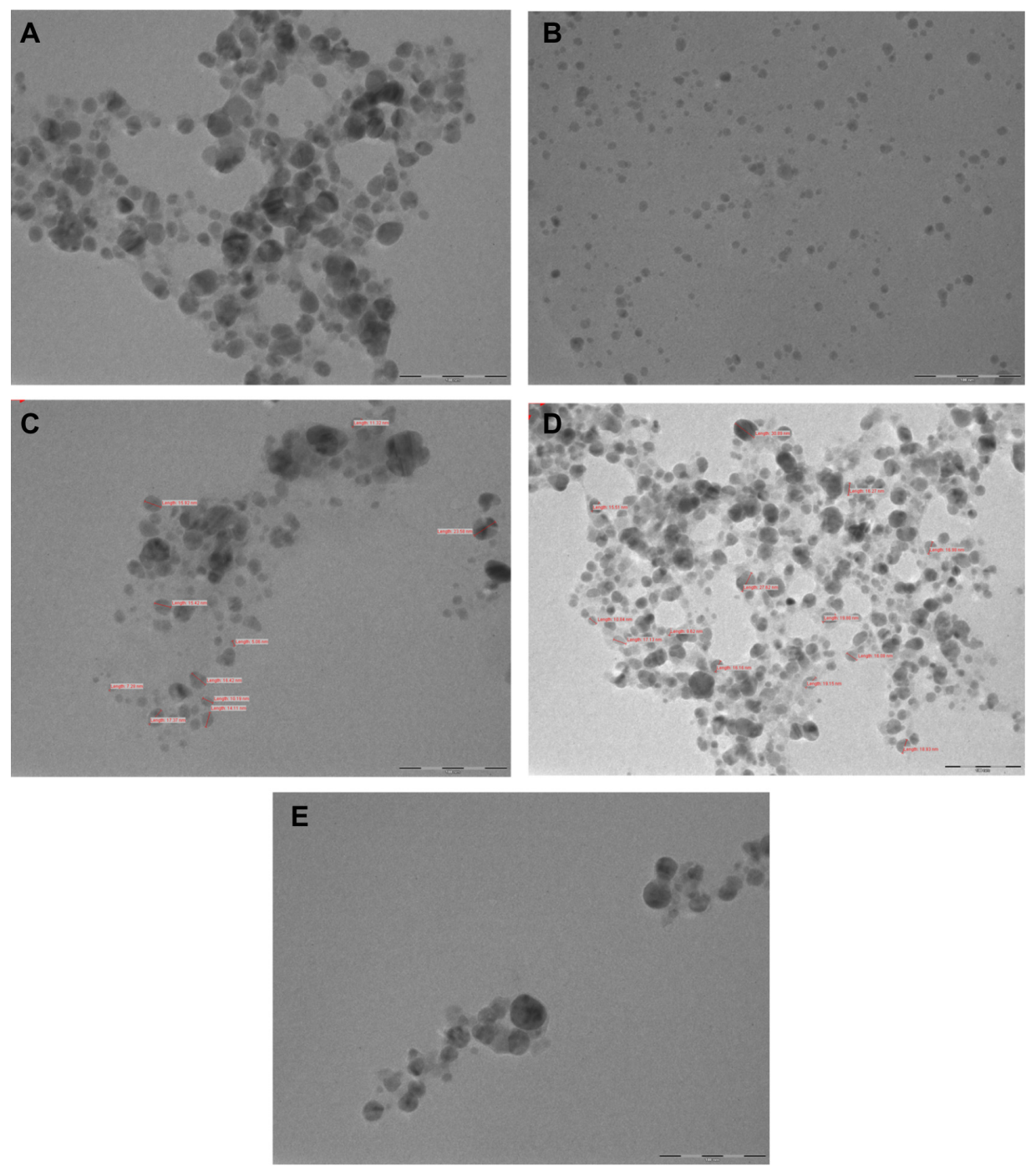

Figure 3 Transmission electron micrographs showing spherical and polydispersed silver nanoparticles. (A) Alternaria species, (B) Fusarium oxysporum, (C) Curvularia species, (D) Chaetomium indicum, and (E) Phoma species (scale $100 \mathrm{~nm}$ ). The diameters of the nanoparticles cover a range of 4-31 nm.

the antiviral assays. We used concentrations ranging from 0.5 to $5 \mu \mathrm{g} / \mathrm{mL}$, therefore well below the level at which cytotoxic effects were observed.

\section{Assessment of antiviral activity}

In order to determine the extent of antiviral activity and elucidate the mechanism of inhibition, we tested AgNPs under different conditions to identify the step in the entry

Table 2 Zeta potential and zeta deviation of silver nanoparticles

\begin{tabular}{llll}
\hline $\mathbf{S N}$ & $\begin{array}{l}\text { AgNPs synthesized } \\
\text { fungi }\end{array}$ & $\begin{array}{l}\text { Zeta potential } \\
(\mathbf{m V})\end{array}$ & $\begin{array}{l}\text { Zeta deviation } \\
(\mathbf{m V})\end{array}$ \\
\hline $\mathrm{I}$ & Alternaria species & -31.5 & 8.98 \\
2 & Fusarium oxysporum & -32.9 & 14.2 \\
3 & Curvularia species & -22.1 & 7.73 \\
4 & Chaetomium indicum & -21.5 & 15.3 \\
5 & Phoma species & -37.0 & 7.67 \\
\hline
\end{tabular}

Abbreviations: $\mathrm{SN}$, sample number; $\mathrm{AgNPs}$, silver nanoparticles. process that may be inhibited by the different nanoparticles. To test whether AgNPs can affect HSV-1, HSV-2 and HPIV-3 infectivity in vitro, we used a cotreatment assay in which the different AgNPs of interest and viruses were concomitantly added to the cell culture in order to have both of them present during and after viral adsorption. The extent of HSV-1, HSV-2, and HPIV-3 replication was assessed by plaque titration after addition of carboxymethyl cellulose.

The results showed a consistent decrease in replication efficiency for HSV-1 and HPIV-3, and a minor effect on the replication of HSV-2 (Figure 4). AgNPs produced by Alternaria species and Phoma species were shown to be toxic at a concentration of $10 \mathrm{mg} / \mathrm{mL}$, the results for this concentration in the antiviral test are not shown in Figure 4B, given that we were not able to determine a reliable viral titer. Also, the inhibition at $5 \mathrm{mg} / \mathrm{mL}$ was not reliable even though we 


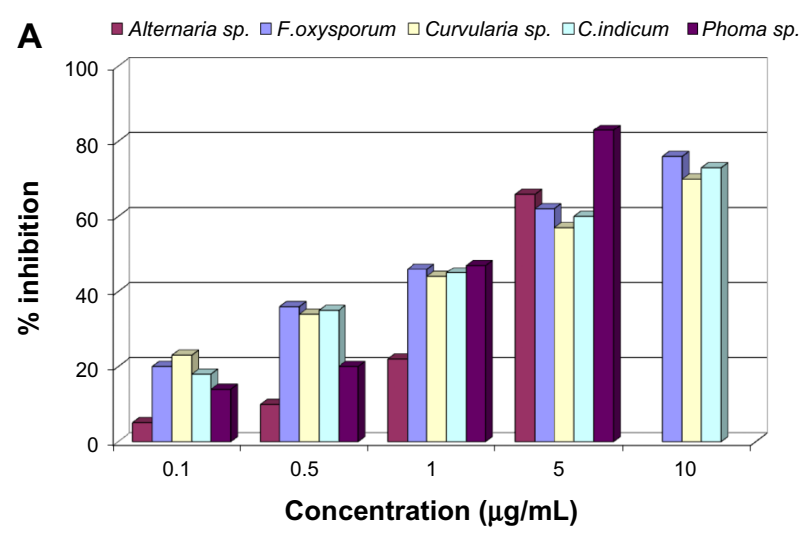

B $\square$ Alternaria sp. $\square$ F.oxysporum $\sqsubset$ Curvularia sp. $\square$ C.indicum $\square$ Phoma $s p$.

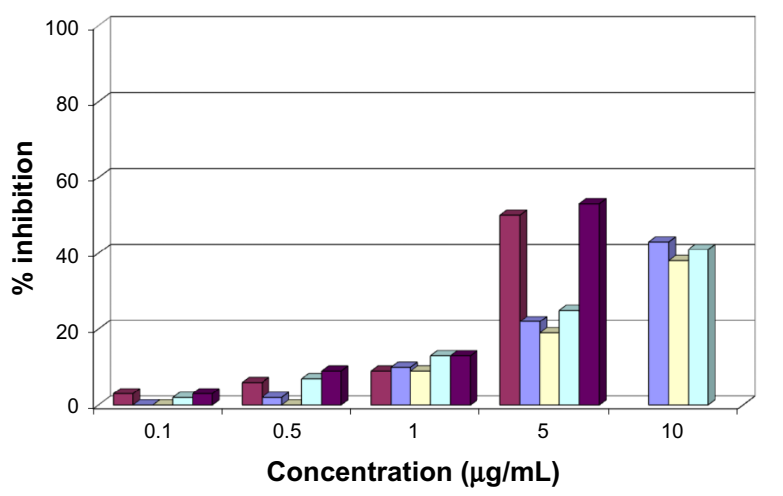

C $\square$ Alternaria sp. $\square$ F.oxysporum $\square$ Curvularia sp. $\square$ C.indicum $\square$ Phoma $s p$.

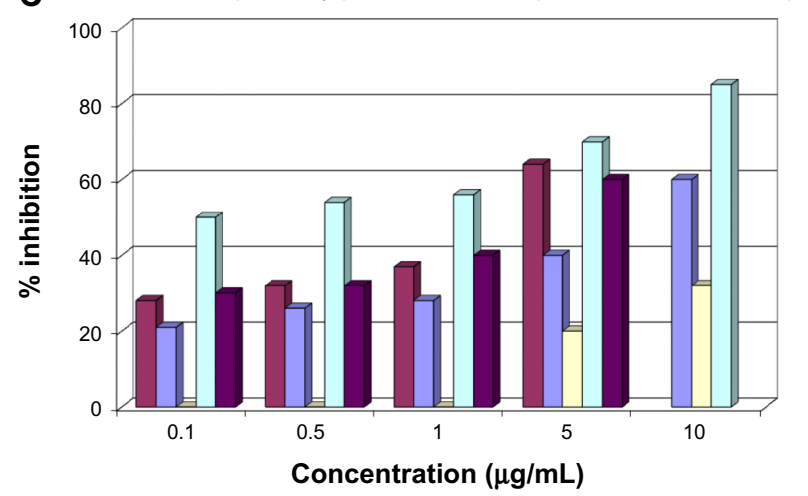

Figure 4 Cotreatment assay. Vero monolayers infected with HSV-I (A), HSV-2 (B), or HPIV-3 (C) were treated with increasing concentrations of silver nanoparticles, then overlain with carboxymethyl cellulose and incubated for 48 hours (HSV-I and HSV-2) or 72 hours (HPIV-3) at $37^{\circ} \mathrm{C}$. Plaque numbers were scored and percent inhibition was calculated with respect to "no-compound" control experiments. The data shown represent the average values for each experiment performed in triplicate.

Abbreviations: HSV-I, herpes simplex virus type I; HSV-2, herpes simplex virus type 2; HPIV-3, human parainfluenza virus type 3 ; sp, species.

could score plaques. The inhibition observed with AgNPs produced by Alternaria species and Phoma species was quite low (between $0 \%$ and $40 \%$ ) with the three viruses at the lower concentrations, so we can conclude that the AgNPs produced by Alternaria and Phoma species are not efficient in reducing viral infectivity. In contrast, AgNPs produced by F. oxysporum and $C$. indicum showed the strongest inhibitory activity, especially toward HSV-1 and HPIV-3. The dose-dependent reduction in virus infectivity can reach $80 \%$ inhibition with AgNPs produced by F. oxysporum when challenged with HSV1, and $90 \%$ inhibition with AgNPs produced by $C$. indicum when challenged with HPIV-3. The results observed when using AgNPs produced by Curvularia species showed that these nanoparticles have inhibitory activity comparable with that of AgNPs produced by F. oxysporum and C. indicum in the case of HSV-1, but almost no inhibitory activity when HPIV-3 was used as the viral challenge.

We further explored the potential of AgNPs to interfere with early penetration. Vero cells were pretreated with the different AgNPs for 1 hour before infection. None of the AgNPs had any inhibitory effect at the concentrations tested on any of the viruses under investigation (Figure 5). This result implies that the AgNPs do not interfere with the cell membrane or early penetration steps of virus entry.

Because inhibition of viral infectivity could be due to a consequence of the action of AgNPs inside the cell at a postentry event, we performed a "post-treatment" test by adding the AgNPs at different concentrations 2 hours after virus infection (Figure 6). Again, AgNPs produced by Alternaria and Phoma species were ineffective as antiviral agents and showed unreliable results due to residual toxicity, while AgNPs produced by F. oxysporum, Curvularia species, and $C$. indicum inhibited the infectivity of the three viruses under study in a dose-dependent manner at levels slightly lower than the ones obtained in the cotreatment assay. Replication of the viruses seemed to be inhibited when the virus and nanoparticles were present on the cell at the same time and therefore during the post-attachment step, and also when the virus had already entered the cells. The latter effect could be due to interference with the replication machinery inside the cells or be a limitation of cell-to-cell spread of viruses after the first replication cycle.

Since inhibition of virus penetration might result from irreversible AgNP-induced inactivation of virions, the possibility that the nanoparticles could interfere with HSV particles and inactivate viral infectivity was explored. To do this, viral aliquots were incubated with different concentrations of the different AgNPs for 2 hours at $37^{\circ} \mathrm{C}$. After incubation, the samples were diluted to reduce the concentrations of the antiviral agent well below the threshold for the resulting viral inhibition, and the infectivity of the preincubated virions was measured by titration on cell monolayers. As shown in Figure 7, incubation of virions with the AgNPs produced by F. oxysporum, Curvularia species, and C. indicum reduced the infectivity in a dose-dependent manner for the three 


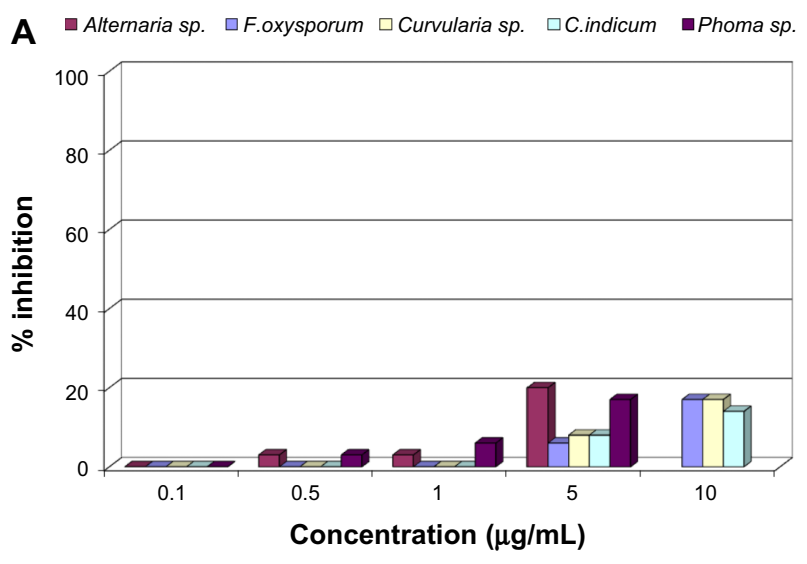

B $\square$ Alternaria sp. $\square$ F.oxysporum $\square$ Curvularia $s p . \quad \square$ C.indicum $\square$ Phoma $s p$.

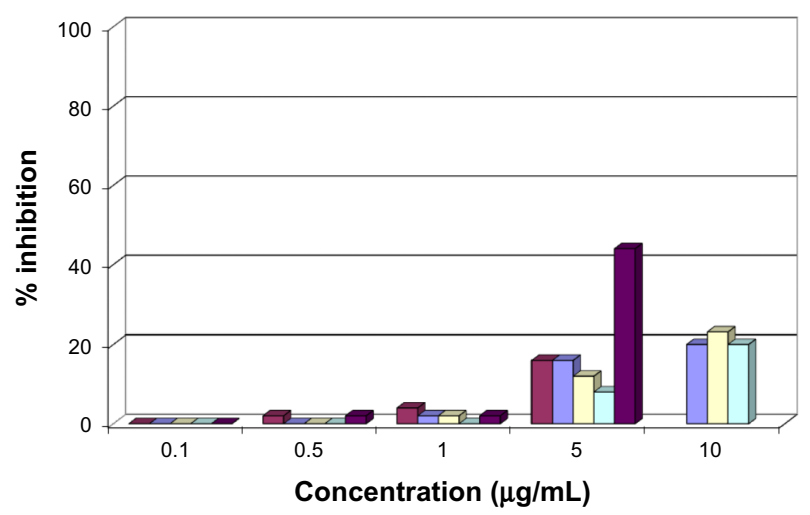

C $\square$ Alternaria sp. $\square$ F.oxysporum $\square$ Curvularia sp. $\square$ C.indicum $\square$ Phoma sp.

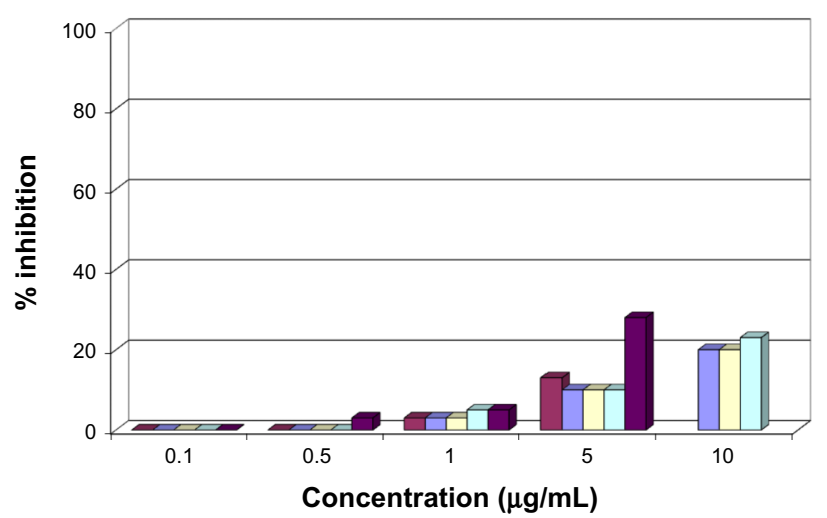

Figure 5 Pretreatment assay. Vero monolayers were treated with increasing concentrations of silver nanoparticles and then infected with HSV-I (A), HSV-2 (B), or HPIV-3 (C), then overlain with carboxymethyl cellulose and incubated for 48 hours (HSV-I and HSV-2) or 72 hours (HPIV-3) at $37^{\circ} \mathrm{C}$. Plaque numbers were scored and percent inhibition was calculated with respect to "no-compound" control experiments. The data shown represent the average values for each experiment performed in triplicate.

Abbreviations: HSV-I, herpes simplex virus type I; HSV-2, herpes simplex virus type 2; HPIV-3, human parainfluenza virus type 3; sp, species.

viruses analyzed. A higher level of inhibition was observed with AgNPs from F. oxysporum and C. indicum. AgNPs produced by Alternaria and Phoma species (not included in Figure 7) confirmed their toxicity toward membrane envelopes, and no plaques were scored, resulting in $100 \%$
A $\square$ Alternaria sp. $\square$ F.oxysporum $\square$ Curvularia $s p . \quad \square$ C.indicum $\square$ Phoma $s p$.

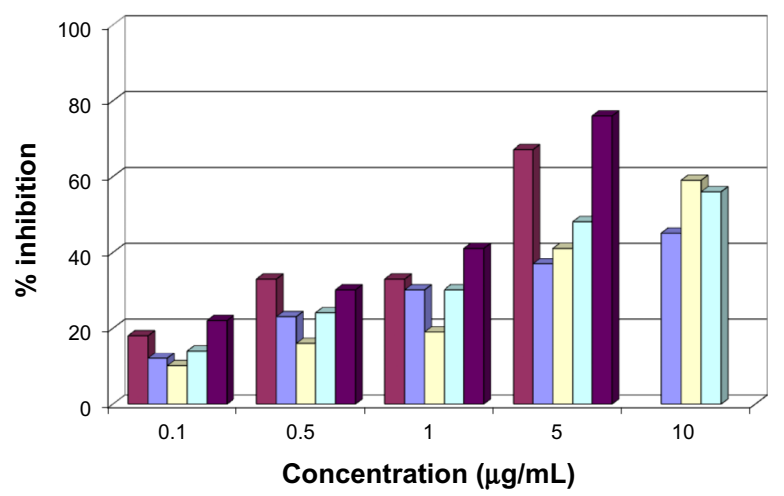

B $\square$ Alternaria $s p . \quad \square$ F.oxysporum $\square$ Curvularia $s p . \quad \square$ C.indicum $\square$ Phoma $s p$.

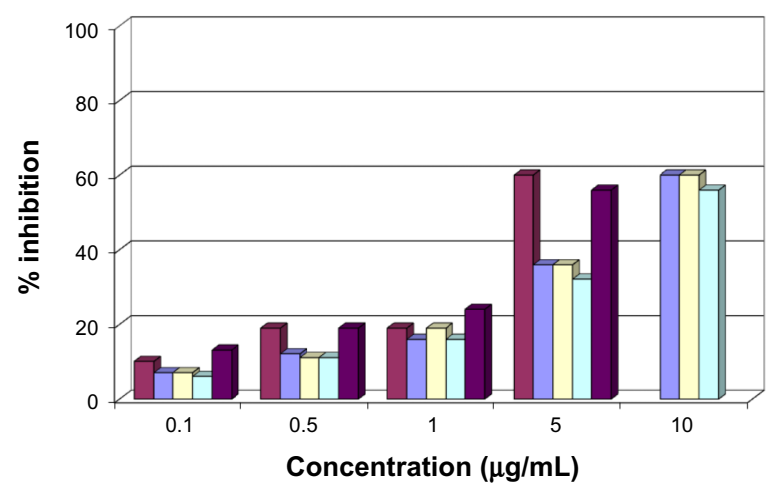

C $\square$ Alternaria $s p . \quad \square$ F.oxysporum $\square$ Curvularia $s p . \quad \square$ C.indicum $\square$ Phoma $s p$.

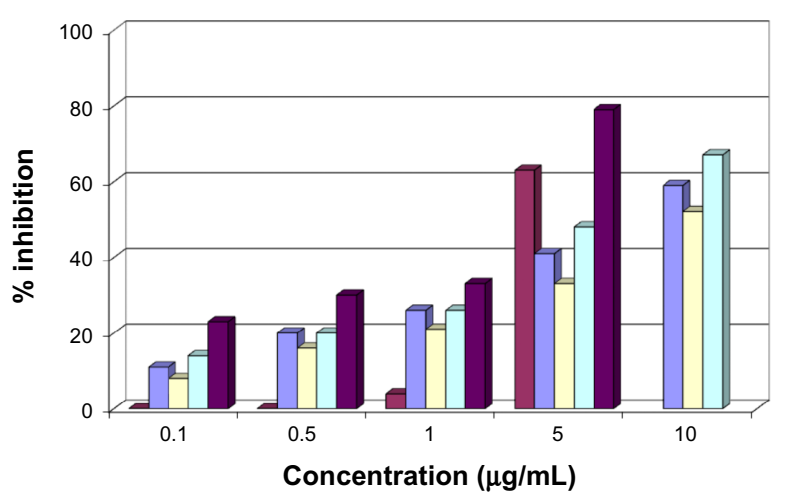

Figure 6 Post-treatment assay. Vero monolayers were infected with HSV-I (A), HSV-2 (B), or HPIV-3 (C), treated with increasing concentrations of silver nanoparticles, overlain with carboxymethyl cellulose, and incubated for 48 hours (HSV-I and HSV-2) or 72 hours (HPIV-3) at $37^{\circ} \mathrm{C}$. Plaque numbers were scored and percent inhibition was calculated with respect to "no-compound" control experiments. The data shown represent the average values for each experiment performed in triplicate.

Abbreviations: HSV-I, herpes simplex virus type I; HSV-2, herpes simplex virus type 2; HPIV-3, human parainfluenza virus type 3; sp, species.

inhibition of infectivity. In the present assay, the inoculum is diluted to a concentration where the amount of AgNPs is markedly reduced under the active concentration. Therefore, we did not observe any toxicity on the cell monolayers, but we can assume that the viral membranes may have been severely impaired and the viruses were unable to infect cells. 

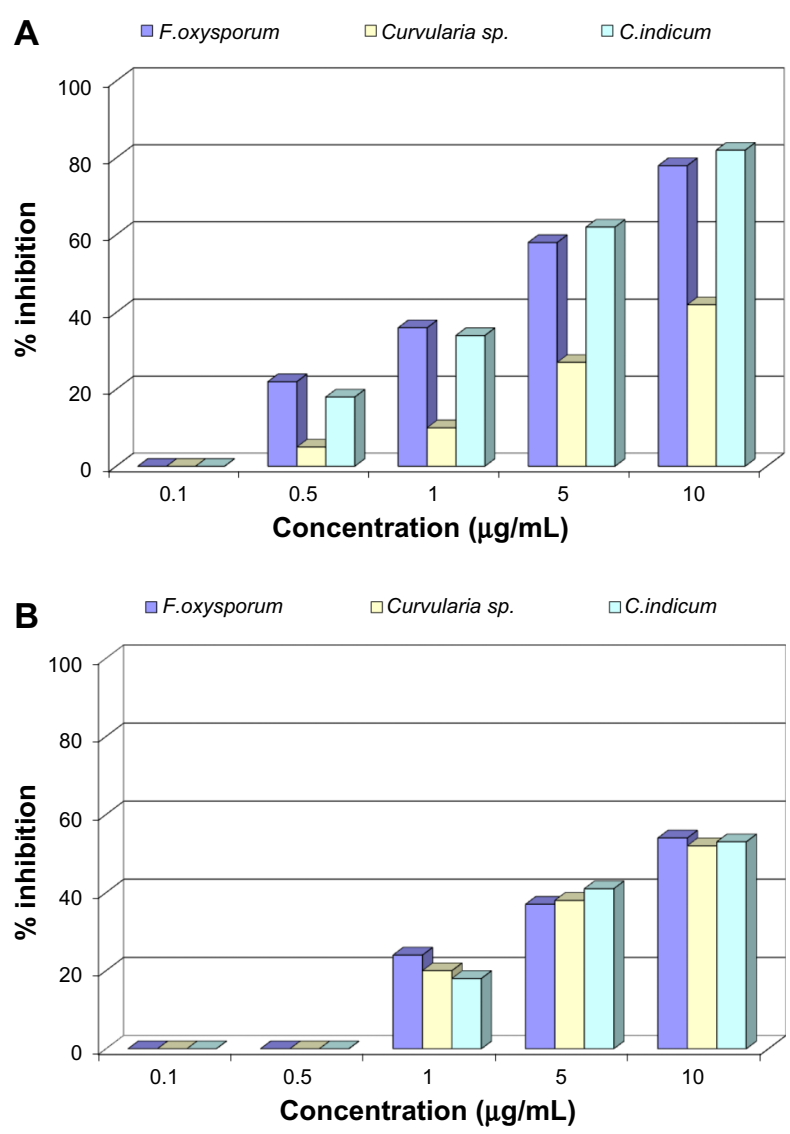

C $\square$ F.oxysporum $\square$ Curvularia $s p . \quad \square$ C.indicum

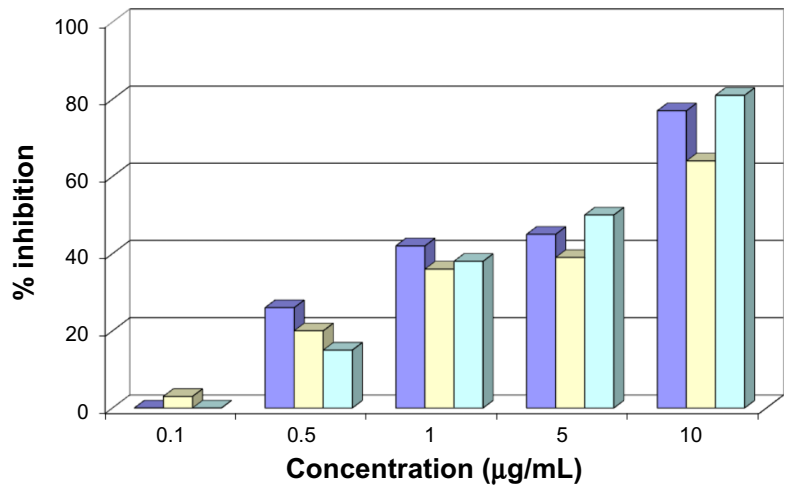

Figure 7 Virus pretreatment assay. Viral aliquots of HSV-I (A), HSV-2 (B), and HPIV-3 (C) were incubated in the presence of different concentrations of silver nanoparticles for 2 hours at $37^{\circ} \mathrm{C}$ and then titrated on cell monolayers. Plaque numbers were scored and percent inhibition was calculated with respect to "nocompound" control experiments. The data shown represent the average values for each experiment performed in triplicate.

Abbreviations: HSV-I, herpes simplex virus type I; HSV-2, herpes simplex virus type 2; HPIV-3, human parainfluenza virus type 3; sp, species.

The results of the virus pretreatment assay show that the nanoparticles also have a virucidal effect.

\section{Conclusion}

We have shown that production of AgNPs from different fungi is feasible, and their antiviral activity is dependent on the production system used. Some of the fungal strains used in the present study resulted in the production of AgNPs with considerable toxicity which prevents their use as antivirals; but some of them, ie, F. oxysporum, Curvularia species, and $C$. indicum, indeed have low toxicity levels and promising antiviral activity. The three viruses investigated belong to the Herpesviridae and Paramyxoviridae families, and all are surrounded by a lipid envelope with embedded viralencoded glycoproteins. Their mechanism of penetration into cells presents several common features; nevertheless they present profound differences in the structural organization of fusion glycoproteins. ${ }^{45,46}$ AgNPs have shown antiviral efficacy against several viruses regardless of the specific structural details of each single family, so may provide the opportunity for developing broad-spectrum antiviral drugs. Nonenveloped viruses are also putative targets of AgNPs, since their exposed capsid surfaces are constituted by proteins that serve as receptor-binding molecules, but no relevant data are as yet available in the literature. AgNPs are able to reduce viral infectivity when added concomitantly with the virus inocula, probably by blocking interaction of the virus with the cell. AgNPs may block an early event before stable binding of the virus with the cell membrane, but it is likely that the nanoparticles interact directly with the viral envelope or its proteins and behave as virucidal agents. In fact, a virus pretreatment assay showed that AgNPs produced in F. oxysporum, Curvularia species, and C. indicum reduced viral infectivity in a dose-dependent manner. Cell pretreatment did not have any measurable effect at the concentration used, so the nanoparticles were not able to clog the receptor sites or the cell surface. The most interesting feature was the interference with replication at the post-entry phase.

From the present study it was observed that AgNPs were capable of controlling viral infectivity, most likely by blocking interaction of the virus with the cell, which might be dependent on the size and zeta potential of the AgNPs. With regard to the influence of size on antiviral activity, it was observed that AgNPs produced by F. oxysporum and Curvularia species, having a size of 4-13 nm and 5-23 nm, respectively, had better antiviral activity (80\%-90\% inhibition) against HSV-1 and HPIV-3 viruses and were less cytotoxic to Vero cells. In contrast, AgNPs produced by Alternaria and Phoma species, with a size range of 7-20 nm, showed less antiviral activity; therefore, AgNPs having a smaller size were able to inhibit replication of the viruses analyzed in this study.

Nanoparticle tracking analysis also revealed that the average size of AgNPs produced by Alternaria and Phoma 
species were $46 \mathrm{~nm}$ and $40 \mathrm{~nm}$, respectively; however, AgNPs synthesized by F. oxysporum and Curvularia species were $20 \mathrm{~nm}$ and $30 \mathrm{~nm}$, respectively, having a smaller size than the former AgNPs. There might also be an impact of zeta potential on antiviral activity. F. oxysporum and Curvularia species produced stable AgNPs with zeta potential values of $-32.9 \mathrm{mV}$ and $-22.1 \mathrm{mV}$, respectively, which showed greater antiviral activity. Alternaria and Phoma species also produced AgNPs having a greater zeta potential, but had a larger particle size and therefore less antiviral activity.

The present findings corroborate the findings of Elechiguerra et $\mathrm{al}^{47}$ who confirmed that smaller-sized AgNPs could attach to a virus, inhibiting the virus from attaching to host cells and ultimately resulting in attenuation of viral replication.

\section{Acknowledgments}

We thank Luca De Luca for technical assistance. We thank MIUR for financial support (towards personalized medicine: new molecular systems for the diagnosis and therapy of oncological diseases with high social impact - Human Health and Biotechnology Scientific Director Professor Carlo Pedone).

\section{Disclosure}

The authors report no conflicts of interest in this work.

\section{References}

1. Tauxe RV. Emerging foodborne pathogens. Int J Food Microbiol. 2002;78:31-41.

2. Domingo E. Mechanisms of viral emergence. Vet Res. 2010;41:38.

3. Field AK, Biron KK. "The end of innocence" revisited: resistance of herpesviruses to antiviral drugs. Clin Microbiol Rev. 1994;7:1-13.

4. Mancini DAP, Torres RP, Pinto JR, Mancini-Filho J. Inhibition of DNA virus: Herpes-1 (HSV-1) in cellular culture replication, through an antioxidant treatment extracted from rosemary spice. Braz J Pharm Sci. 2009;45:127.

5. Hashem AM, Flaman AS, Farnsworth A, et al. Aurintricarboxylic acid is a potent inhibitor of influenza $\mathrm{A}$ and $\mathrm{B}$ virus neuraminidases. PLoS One. 2009;4:e8350.

6. Singh R, Nalwa HS. Medical applications of nanoparticles in biological imaging, cell labeling, antimicrobial agents, and anticancer nanodrugs. J Biomed Nanotechnol. 2011;7:489-503.

7. Nair B, Pradeep T. Coalescence of nanoclusters and formation of submicron crystallites assisted by lactobacillus strains. Cryst Growth Des. 2002;2:293-298.

8. Ahmad A, Senapati S, Khan MI, et al. Intracellular synthesis of gold nanoparticles by a novel alkalotolerant actinomycete, Rhodococcus species. Nanotechnology. 2003;14:824-828.

9. Robinson MG, Brown LN, Hall BD. Effect of gold (III) on the fouling diatom Amphora coffeaeformis: uptake, toxicity and interactions with copper. Biofouling. 1997;11:59-79.

10. Gardea-Torresdey JL, Gomez E, Peralta-Videa JR, Parsons JG, Troiani H, Jose-Yacaman M. Alfalfa sprouts: a natural source for the synthesis of silver nanoparticles. Langmuir. 2003;19:1357-1361.
11. Kesharwani JG, Rai MK, Hwang J, Yoon KI. Phytofabrication of silver nanoparticles by leaf extract of Daturametel: hypothetical mechanism involved in synthesis. Journal of Bionanoscience. 2009;3:39-44.

12. Bonde SR, Rathod DP, Ingle AP, Ade RB, Gade AK, Rai MK. First report of Murraya koenigii mediated synthesis of silver nanoparticles and its activity against three human pathogenic bacteria. Nanoscience Methods. 2012;1:25-36.

13. Gade AK, Bonde PP, Ingle AP, Marcato PD, Duran N, Rai MK. Exploitation of Aspergillus niger for fabrication of silver nanoparticles. $J$ Biobased Mater Bio. 2008;2:243-247.

14. Birla SS, Tiwari VV, Gade AK, Ingle AP, Yadav AP, Rai MK. Fabrication of silver nanoparticles by Phoma glomerata and its combined effect against Escherichia coli, Pseudomonas aeruginosa and Staphylococcus aureus. Lett Appl Microbiol. 2009;48:173-179.

15. Gajbhiye M, Kesharwani J, Ingle A, Gade A, Rai M. Fungus-mediated synthesis of silver nanoparticles and their activity against pathogenic fungi in combination with fluconazole. Nanomedicine. 2009;5: 382-386.

16. Ingle A, Gade A, Pierrat S, Sonnichsen C, Rai M. Mycosynthesis of silver nanoparticles using the fungus Fusarium acuminatum and its activity against some human pathogenic bacteria. Curr Nanosci. 2008;4: 141-144.

17. Ingle A, Rai M, Gade A, Bawaskar M. Fusarium solani: a novel biological agent for the extracellular synthesis of silver nanoparticles. J Nanopart Res. 2009;11:2079-2085.

18. Fayaz AM, Balaji K, Girilal M, Yadav R, Kalaichelvan PT, Venketesan R. Biogenic synthesis of silver nanoparticles and their synergistic effect with antibiotics: a study against Gram-positive and Gram-negative bacteria. Nanomedicine. 2010;6:103-109.

19. Raheman F, Deshmukh S, Ingle A, Gade A, Rai M. Silver nanoparticles: novel antimicrobial agent synthesized from an endophytic fungus pestalotia sp. isolated from leaves of Syzygium cumini (L). Nano Biomed Eng. 2011;3:174-178.

20. Li G, He D, Qian Y, et al. Fungus-mediated green synthesis of silver nanoparticles using Aspergillus terreus. Int J Mol Sci. 2012;13: 466-476.

21. Moazeni M, Rashidi N, Shahverdi AR, Noorbakhsh F, Rezaie S. Extracellular production of silver nanoparticles by using three common species of dermatophytes: Trichophyton rubrum, Trichophyton mentagrophytes and Microsporum canis. Iran Biomed J. 2012;16: 52-58.

22. Jogee PS, Ingle AB, Gupta IR, Bonde SR, Rai MK. Detection and management of mycotoxigenic fungi in nuts and dry fruits. Acta Hortic. 2012;963:69.

23. Cao XL, Cheng C, Ma YL, Zhao CS. Preparation of silver nanoparticles with antimicrobial activities and the researches of their biocompatibilities. J Mater Sci Mater Med. 2010;21:2861-2868.

24. Devi LS, Joshi SR. Antimicrobial and synergistic effects of silver nanoparticles synthesized using soil fungi of high altitudes of eastern himalaya. Mycobiology. 2012;40:27-34.

25. You C, Han C, Wang X, et al. The progress of silver nanoparticles in the antibacterial mechanism, clinical application and cytotoxicity. Mol Biol Rep. 2012;39:9193-9201.

26. Galdiero S, Falanga A, Vitiello M, Cantisani M, Marra V, Galdiero M. Silver nanoparticles as potential antiviral agents. Molecules. 2011;16: 8894-8918.

27. Rogers JV, Parkinson CV, Choi YW, Speshock JL, Hussain SM. A preliminary assessment of silver nanoparticles inhibition of Monkeypox virus plaque formation. Nanoscale Res Lett. 2008;3:129-133.

28. Speshock JL, Murdock RC, Braydich-Stolle LK, Schrand AM, Hussain SM. Interaction of silver nanoparticles with Tacaribe virus. J Nanobiotechnol. 2010;8:19.

29. Lara HH, Ayala-Nunez NV, Ixtepan-Turrent L, Rodriguez-Padilla C. Mode of antiviral action of silver nanoparticles against HIV-1. J Nanobiotechnol. 2010;8:1.

30. Lu L, Sun RW, Chen R, et al. Silver nanoparticles inhibit hepatitis B virus replication. Antivir Ther. 2008;13:253-262. 
31. Sun L, Singh AK, Vig K, Pillai S, Shreekumar R, Singh SR. Silver nanoparticles inhibit replication of respiratory syncytial virus. J Biomed Biotechnol. 2008;4:149-158.

32. Baram-Pinto D, Shukla S, Perkas N, Gedanken A, Sarid R. Inhibition of herpes simplex virus type 1 infection by silver nanoparticles capped with mercaptoethane sulfonate. Bioconjug Chem. 2009;20:1497-1502.

33. Mehrbod P, Motamed N, Tabatabaian M, et al. In vitro antiviral effect of "nanosilver" on influenza virus. DARU. 2009;17:88-93.

34. Galdiero S, Falanga A, Vitiello M, et al. Peptides containing membraneinteracting motifs inhibit herpes simplex virus type 1 infectivity. Peptides. 2008;29:1461-1471.

35. Patil HB, Borse SV, Patil DR, Patil UK, Patil HM. Synthesis of silver nanoparticles by microbial method and their characterization. Arch Phys Res. 2011;2:155-158.

36. Moharrer S, Mohammadi B, Gharamohammadi RA, Yargoli M. Biological synthesis of silver nanoparticles by Aspergillus flavus, isolated from soil of Ahar copper mine. Indian J Sci Technol. 2012;5: 2443-2444.

37. Bawaskar M, Gaikwad S, Ingle A, et al. A new report on mycosynthesis of silver nanoparticles by Fusarium culmorum. Curr Nanosci. 2010;6: 376-380.

38. Chan YS, Mashitah MD. Instantaneous biosynthesis of silver nanoparticles by selected macro fungi. Aust J Basic Appl Sci. 2012;6: 222-226.

39. Vahabi K, Mansoori GA, Karimi S. Biosynthesis of silver nanoparticles by fungus Trichoderma reesei. Insciences J. 2011;1:65-79.
40. Sangappa M, Thiagarajan P. Mycobiosynthesis and characterization of silver nanoparticles from Aspergillus niger: a soil fungal isolate. International Journal of Life Sciences Biotechnology and Pharma Research. 2012;1:282.

41. Ahmad A, Mukherjee P, Senapati S, et al. Extracellular biosynthesis of silver nanoparticles using the fungus Fusarium oxysporum. Colloids Surf B. 2003;28:313-319.

42. Montes-Burgos I, Walczyk D, Hole P, Smith J, Lynch I, Dawson K. Characterisation of nanoparticle size and state prior to nanotoxicological studies. J Nanopart Res. 2010;12:47-53.

43. Wright M. NanoParticle tracking analysis for the multiparameter characterization and counting of nanoparticle suspensions. In: Soloviev M, editor. Nanoparticles in Biology and Medicine. New York, NY: Humana Press; 2012.

44. Salem HF, Eid K, Sharaf MA. Formulation and evaluation of silver nanoparticles as antibacterial and antifungal agents with a minimal cytotoxic effect. Int J Drug Deliv. 2011;3:293-304.

45. Connolly SA, Jackson JO, Jardetzky TS, Longnecker R. Fusing structure and function: a structural view of the herpes virus entry machinery. Nat Rev Microbiol. 2011;9:369-381.

46. Chang A, Dutch RE. Paramyxovirus fusion and entry: multiple paths to a common end. Viruses. 2012;4:613-636.

47. Elechiguerra JL, Burt JL, Morones JR, et al. Interaction of silver nanoparticles with HIV-1. J Nanobiotechnol. 2005;3:6.
International Journal of Nanomedicine

\section{Publish your work in this journal}

The International Journal of Nanomedicine is an international, peerreviewed journal focusing on the application of nanotechnology in diagnostics, therapeutics, and drug delivery systems throughout the biomedical field. This journal is indexed on PubMed Central, MedLine, CAS, SciSearch ${ }^{\circledR}$, Current Contents ${ }^{\circledR} /$ Clinical Medicine,

\section{Dovepress}

Journal Citation Reports/Science Edition, EMBase, Scopus and the Elsevier Bibliographic databases. The manuscript management system is completely online and includes a very quick and fair peer-review system, which is all easy to use. Visit http://www.dovepress.com/ testimonials.php to read real quotes from published authors. 